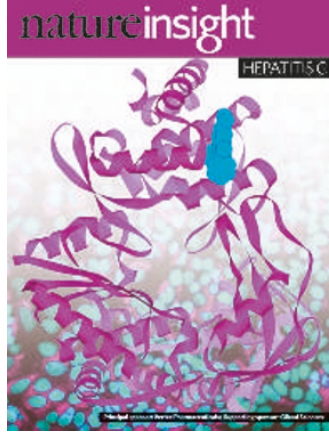

Cover illustration

The cells are from the recently developed robust in vitro hepatitis $C$ virus (HCV) infection system. Pink staining indicates the presence of the HCV protein NS5A. (Courtesy of F. Chisari.) The crystal structure is of the $\mathrm{HCV}$ polymerase NS5B in complex with an inhibitor. (Courtesy of R. De Francesco \& G. Migliaccio.)

\section{Editor, Nature Philip Campbell Insights Publisher Sarah Greaves \\ Insights Editor Lesley Anson \\ Production Editor Maria Hodges}

Senior Art Editor Martin Harrison

Art Editor

Nik Spencer

Layouts

Clifford Saunders

Sponsorship

Claire Hines

Production

Sue Gray

Marketing

Claire Aspinall

Editorial Assistant Laura Shaw

\title{
HEPATITIS C
}

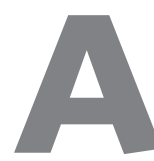
n estimated $3 \%$ of the world's population — more than 170 million people - are infected by the hepatitis $\mathrm{C}$ virus (HCV). Most infections become chronic: a condition that is incurable in many patients, leading to cirrhosis, end-stage liver disease and hepatocellular carcinoma. Current medical treatment options are limited, and 10,000 to 20,000 deaths a year in the United States are from hepatitis C. Indeed, chronic HCV infection is the most common cause of liver transplantation.

Despite the discovery of the virus by molecular biological methods more than 15 years ago, and the sequencing of its entire genome, our knowledge of the virus and the nature of the protective immune responses is limited. Researchers have been hampered by the lack of a robust cell-culture system yielding infectious virus until very recently, and the absence of a non-primate animal model.

Nevertheless, great strides have been made over the past few years, and much has been learned about the viral life cycle, immune response factors that confer protection, and the mechanisms by which the virus is able to evade the host immune response. New drugs are on the horizon and a protective vaccine may be within reach. This Insight brings together leading experts in hepatitis $\mathrm{C}$ to provide a snapshot of the field and discuss imminent developments.

We are pleased to acknowledge the financial support of Vertex Pharmaceuticals and Gilead Sciences, which together contributed towards the production of this Insight. As always, Nature carries sole responsibility for all editorial content and peer review.

\section{Ursula Weiss, Senior Editor}

\section{INTRODUCTION}

930 Unscrambling hepatitis C virus-host interactions

F. V. Chisari

\section{REVIEW ARTICLES}

933 Unravelling hepatitis $C$ virus replication from genome to function

B. D. Lindenbach \& C. M. Rice

939 Evasion of intracelllular host defence by hepatitis $C$ virus M. Gale Jr \& E. M. Foy

946 Adaptive immune responses in acute and chronic hepatitis $C$ virus infection

D. G. Bowen \& C. M. Walker

953 Challenges and successes in developing new therapies for hepatitis C

R. De Francesco \& G. Migliaccio

961 Prospects for a vaccine against the hepatitis $C$ virus M. Houghton \& S. Abrignani

967 Mechanism of action of interferon and ribavirin in treatment of hepatitis $\mathbf{C}$ J. J. Feld \& J. H. Hoofnagle

973 Hepatitis C and liver transplantation

R. S. Brown Jr

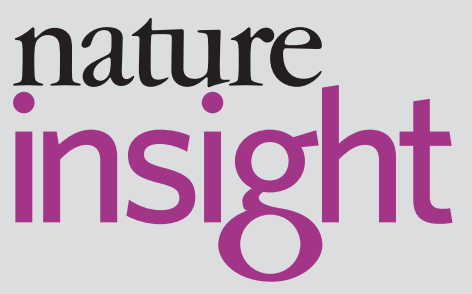

